\title{
Estrogen Receptor Positive by Immunohistochemistry 91-100 Percent
}

National Cancer Institute

\section{Source}

National Cancer Institute. Estrogen Receptor Positive by Immunohistochemistry 91-100

Percent. NCI Thesaurus. Code C141476.

An immunohistochemical staining finding indicating that 91-100 percent of the cells in a tissue sample are expressing estrogen receptor. 